\author{
Remigiusz Żulicki \\ University of Łódź \\ Institute of Sociology \\ Department of Sociology of Culture \\ remigiusz.zulicki@uni.Eódź.pl
}

\title{
THE EMPLOYMENT OF ŁÓDŹ UNIVERSITY TOURISM AND RECREATION GRADUATES: A SOCIOLOGICAL ANALYSIS
}

\begin{abstract}
This article is focused on selected aspects of the economic 'fate' of Tourism and Recreation graduates of the University of Łódź (UŁ). Its aim is to seek answers to the question: 'What determines graduate employment?' Surveys conducted by the Career Office of University of Łódź among graduates one year after graduation in 2014, 2015 and 2016 are the empirical basis. Tourism and Recreation graduates were compared with others from the Faculty of Geographical Sciences UŁ. The logistic regression technique was used to predict the status of graduate employment based on independent variables. The strongest predictors of graduate employment were structural and institutional characteristics. The quantitative results were interpreted in the context of the modern role of universities.
\end{abstract}

Keywords: graduate, employment, university, logistic regression.

\section{INTRODUCTION}

The article is focused on selected aspects of the economic 'fate' (as it is called by the Ministry of Science and Higher Education in Poland ela.nauka.gov.pl) of Tourism and Recreation (TR) students of the Faculty of Geographical Sciences (FGS) at the University of Łódź (UŁ). Its aim is to seek answers to the question: 'What determines the status of graduate employment?' Employment status is understood through the declaration of graduates: 'I work now/I do not work now'. The empirical basis is surveys, conducted by the University of Łódź among graduates one year after graduation in 2014, 2015 and 2016. TR graduates were compared with others from FGS UŁ. The quantitative results were interpreted in the context of the modern role of universities.

\section{LITERATURE REVIEW}

The need for research studies like those reported here were recognized in Poland in the 1920s. According to L. PAŁASZ (2004, p. 5): "Probably the first research into graduates from higher education institutions in Poland was undertaken by Antoni Bolesław Dobro- wolski in 1923. His goal was to adapt education to the needs of the contemporary labour market, and his basic research question was whether graduates really received skills more or less similar to what they would really do in their job" (PAŁASZ 2004, p. 5). In the early 1950s, Wołoszyn undertook this type of research, and in the second half of 1950s the Sociological Research Department of the Polish Academy of Science, led by Szczepański, completed the first comprehensive study of graduate professional careers. J. Szczepański later published Socjologiczne zagadnienia wyższego wyksztatcenia, where he pointed out the theoretical basis and research methods of graduate careers studies (SZCZEPANSKI 1963). The terms introduced in his work were the 'assumed function' and 'real function' of a university. The first of these is the basic idea of a university, understood as those values formalized in its statutes, while 'real functions' are those met by a university in response to public demand (SZCZEPAŃSKI 1963, pp. 16-18). Therefore, this article is devoted the real function.

Tourism and recreation as a field of study was established in Poland in the 70s at several academies of physical education, currently it is available both at private colleges and public universities (LISZEWSKI 
2010). The authors of the latest nationwide survey: "The fate of graduates from schools and universities training personnel for tourism", conducted for the Ministry of Sport and Tourism, paid attention to tourism as one of the fastest growing and most profitable sectors of the economy (ZARZECKI et al. 2010). The report contains a series of simple summaries of the data collected, tables and charts, with some descriptive statistics. The advantage of this study is the random sampling method used (PPS - Probability Proportional to Size) $n=500$ (for graduates), consistent with the methodology of the Central Statistical Office ZARZECKI et al. 2010, p. 19). The report lacks statistical hypothesis testing and modelling. Much more statistically and substantively advanced is Przechodzenie absolwentów studiów geograficznych na rynek pracy. Proces, czynniki, predykcja. The author has set his goal "to clarify the conditions, mechanisms, processes and determination of the transition process of university graduates in Poland, as exemplified by graduates of geography" (PIRÓG 2015, p. 26). Transition is understood here as the "transition of graduates from different levels of education to employment" (PIRÓG 2015 , p. 26). The two-stage study on a sample of 1,120 volunteers from twelve Polish universities also included those specialising in the field of tourism - they accounted for about $10 \%$ of the respondents (PIRÓG 2015, p. 94). The modelling technique 'stepwise discriminant analysis' used a sample $n=375$, these graduates were surveyed six months after graduation and the dependent variable was the status of graduate employment considered in terms of 'working/not working' (PIRÓG 2015, p. 145). Unfortunately, the study included only full-time graduates (PIRÓG 2015, p. 32), so the results lead to an incomplete comparability - the mode of study proved to be one of the most important predictors of FGS UŁ graduate employment status (see section "Model of graduate employment status"). Be that as it may, comparison of models - proposed here and in Piróg's book - will be presented later because of their cognitive value.

\section{METHODS AND RESEARCH TECHNIQUE}

The research material has been collected and made available by the Career Office of the University of Łódź within the framework "Monitoring careers of graduates of UŁ" (biurokarier.uni.Łódź.pl). It is a "cyclic panel study', carried out for the authorities of the university and its faculties. Surveys were undertaken a year after graduation: 2012/13, 2013/14 and 2014/15. This was the 'first round' of the panel. The moment of the end of education is considered here as the academic year in which the last exam before the thesis defence is taken. Surveys are university-wide: include all twelve UŁ faculties in Łódź and branches in Tomaszów, all modes (full-time and part-time) and the types of degrees (undergraduate, graduate and ten semester master's studies) graduating each academic year.

The Career Office uses CAWI (Computer Assisted Web Interview) forms, implemented on the Lime Survey. The answers are collected annually from April to June. The scope of the research concerns:

- the socio-demographic characteristics of those surveyed,

- type, mode, faculty and field of degrees,

- additional activities undertaken in the course of acquiring higher education,

- current employment of graduates,

- the situation of unemployed graduates,

- further vocational and educational plans,

- evaluation of the degree course at the University of Łódź.

In total, the questionnaire consists of 69 items. Given the purpose and scope of this article the issues listed in paragraphs 5, 6 and 7 are omitted here.

Career Office surveys are consistent and varied little, making it possible to merge data on graduates from different years. All transformations (filter out FGS graduate records from university-wide data sheets, merge data from three different years in one sheet, recoding variables), analysis (statistical tests and logistic regression model) and summaries of data (tables and graphs) were made using IBM SPSS Statistics 24.0.0.0. Assumed typical social science significance level $a=$ 0.05 .

\section{CHARACTERISTICS OF THE STUDY GROUP}

The CAWI questionnaire is sent by email only to those who agreed to participate in the monitoring. Consents were collected by clearance slips. In 2014, 2015, 2016 respectively, 1545, 1491 and 1023 responses were obtained (Table 1).

Thus, a proportion of about $11 \%$ (2013-14) to $16 \%$ (other years) of total graduates in a particular year took part in surveys. These samples are not representative, but the gender, type and mode of study structure of respondents are similar to the overall characteristics. In addition, the sample is made up of volunteers, which always results in level of bias being unknown. A typical example is American sexual behaviour survey on a sample of volunteers, carried out in the 1950s. Subsequent research has shown that above average sexually active people were overrepresented (BRZEZINSKI 2003, p. 232). Perhaps when 
monitoring the careers of graduates the respondents might be more strongly emotionally connected with the university than those who did not agree to participate or expressed consent, but later did not respond to the CAWI form.

Table 1. Implementation of 'Monitoring the careers of UŁ graduates' (first round) in 2014-16

\begin{tabular}{|l|c|c|c|}
\hline \multirow{2}{*}{} & \multicolumn{3}{|c|}{ Year of survey } \\
\cline { 2 - 4 } & 2014 & 2015 & 2016 \\
\hline Academic year of graduation & $2012 / 13$ & $2013 / 14$ & $2014 / 15$ \\
\hline UŁ graduate population $(N)$ & 9,844 & 9,631 & 9,844 \\
\hline $\begin{array}{l}\text { Consent to participate in the } \\
\text { study }(N)\end{array}$ & 4,109 & 3,396 & 3,775 \\
\hline Survey responses $(N)$ & 1,545 & 1,023 & 1,491 \\
\hline Consent/ Population (\%) & 41.7 & 35.3 & 41.4 \\
\hline Responses/ Population $(\%)$ & 15.7 & 10.6 & 16.4 \\
\hline Responses/ Consent $(\%)$ & 37.6 & 30.1 & 39.5 \\
\hline
\end{tabular}

Source: Career Office, University of Łódź.

For this study, the group of respondents was limited to graduates of FGS, 340 in total. No responses occurred in nine cases (item nonresponse), so the full figure was 331. Nineteen respondents participated twice - 2012/ 13 as bachelors and 2014/15 as masters. Any such person is treated as two independent units of analysis because this article does not compare dependent groups by time. Table 2 shows the surveyed FGS group divided into fields of study.

Table 2. FGS UŁ graduates by all fields of study

\begin{tabular}{|l|r|r|}
\hline \multicolumn{1}{|c|}{ Field of study } & $\begin{array}{c}\text { No. of } \\
\text { graduates }\end{array}$ & Percentage \\
\hline Geography & 92 & 27.1 \\
\hline Teaching Geography & 38 & 11.2 \\
\hline Geomonitoring & 21 & 6.2 \\
\hline Geoinformation & 2 & 0.6 \\
\hline Spatial Economy & 99 & 29.1 \\
\hline Regional Studies & 6 & 1.8 \\
\hline Tourism \& Recreation & 78 & 22.9 \\
\hline Ecophysiography \& Geoecology & 2 & 0.6 \\
\hline Urban Geography & 1 & 0.3 \\
\hline Climatology & 1 & 0.3 \\
\hline Total & 340 & 100.0 \\
\hline
\end{tabular}

Source of data for Tables 2-14: author based on 'Monitoring careers of UŁ graduates'.

Table 3. FGS UŁ graduate field of study by year of graduation

\begin{tabular}{|l|c|c|c|c|c|c|c|c|}
\hline \multirow{3}{*}{$\begin{array}{c}\text { Field of } \\
\text { study }\end{array}$} & \multicolumn{7}{|c|}{ Academic year } & \multicolumn{3}{c|}{ Total } \\
\cline { 2 - 10 } & $2012 / 2013$ & $2013 / 2014$ & $2014 / 2015$ & & \\
\cline { 2 - 9 }$n$ & $N$ & $\%$ & $N$ & $\%$ & $N$ & $\%$ & $N$ & $\%$ \\
\hline Other & 85 & 78.7 & 79 & 76.0 & 98 & 76.6 & 262 & 77.1 \\
\hline $\begin{array}{l}\text { Tourism \& } \\
\text { Recreation }\end{array}$ & 23 & 21.3 & 25 & 24.0 & 30 & 23.4 & 78 & 22.9 \\
\hline Total & 108 & 100.0 & 104 & 100.0 & 128 & 100.0 & 340 & 100.0 \\
\hline
\end{tabular}

TR graduates were the third largest group $(n=78)$. In the following sections, all other fields of study are grouped in an 'Other' category. In each of the surveyed years TR graduates constituted over 20\% (Table 3 ).

Part-time graduates were only one tenth of FGS. About $19 \%$ of TR graduates were part-time (Table 4 ).

Table 4. FGS UŁ graduates mode of study by field of study

\begin{tabular}{|l|r|r|r|r|r|r|}
\hline \multirow{2}{*}{$\begin{array}{c}\text { Mode } \\
\text { of study }\end{array}$} & \multicolumn{2}{|c|}{ Other } & \multicolumn{2}{c|}{$\begin{array}{c}\text { Tourism \& } \\
\text { Recreation }\end{array}$} & \multicolumn{2}{c|}{ Total } \\
\cline { 2 - 7 } & \multicolumn{1}{|c|}{$N$} & \multicolumn{1}{c|}{$\%$} & $N$ & \multicolumn{1}{c|}{$\%$} & \multicolumn{1}{c|}{$N$} & \multicolumn{1}{c|}{$\%$} \\
\hline Full-time & 244 & 93.1 & 63 & 80.8 & 307 & 90.3 \\
\hline Part-time & 18 & 6.9 & 15 & 19.2 & 33 & 9.7 \\
\hline Total & 262 & 100.0 & 78 & 100.0 & 340 & 100.0 \\
\hline
\end{tabular}

In terms of field of study proportions were similar for FGS, TR and other fields. Bachelor degrees made up a little over one third of each group (Table 5).

Table 5. FGS UŁ graduate type by field of study

\begin{tabular}{|l|c|c|c|c|c|c|}
\hline \multirow{2}{*}{\begin{tabular}{c}
\multirow{2}{*}{$\begin{array}{c}\text { Type } \\
\text { of study }\end{array}$} \\
\cline { 2 - 7 }
\end{tabular}} & \multicolumn{2}{|c|}{ Other } & \multicolumn{2}{c|}{$\begin{array}{c}\text { Tourism \& } \\
\text { Recreation }\end{array}$} & \multicolumn{2}{c|}{ Total } \\
\cline { 2 - 7 } & $N$ & $\%$ & $N$ & $\%$ & $N$ & $\%$ \\
\hline Bachelor & 90 & 34.4 & 30 & 38.5 & 120 & 35.3 \\
\hline Master & 172 & 65.6 & 48 & 61.5 & 220 & 64.7 \\
\hline Total & 262 & 100.0 & 78 & 100.0 & 340 & 100.0 \\
\hline
\end{tabular}

Less than $2 \%$ of respondents lived outside Poland. TR graduates lived abroad slightly more likely than other FGS graduates. Respondents indicated only Northern European countries (Table 6).

Table 6. FGS UŁ graduate country of residence by field of study

\begin{tabular}{|l|r|r|r|r|r|r|}
\hline \multirow{2}{*}{$\begin{array}{c}\text { Country } \\
\text { of residence }\end{array}$} & \multicolumn{2}{|c|}{ Other } & \multicolumn{2}{c|}{$\begin{array}{c}\text { Tourism \& } \\
\text { Recreation }\end{array}$} & \multicolumn{2}{c|}{ Total } \\
\cline { 2 - 7 } & \multicolumn{1}{|c|}{$N$} & \multicolumn{1}{c|}{$\%$} & $N$ & \multicolumn{1}{c|}{$\%$} & \multicolumn{1}{c|}{$N$} & \multicolumn{1}{c|}{$\%$} \\
\hline Poland & 259 & 98.9 & 75 & 96.2 & 334 & 98.2 \\
\hline Northern Europe & 3 & 1.1 & 3 & 3.8 & 6 & 1.8 \\
\hline Total & 262 & 100.0 & 78 & 100.0 & 340 & 100.0 \\
\hline
\end{tabular}

About $9.5 \%$ of respondents lived outside Łódź voivodship. The percentage was slightly higher for TR graduates (Table 7).

Table 7. FGS UŁ graduate voivodship of residence by field of study

\begin{tabular}{|l|r|r|r|r|r|r|}
\hline \multirow{2}{*}{$\begin{array}{c}\text { Voivodship } \\
\text { of residence }\end{array}$} & \multicolumn{2}{|c|}{ Other } & \multicolumn{2}{c|}{$\begin{array}{l}\text { Tourism \& } \\
\text { Recreation }\end{array}$} & \multicolumn{2}{c|}{ Total } \\
\cline { 2 - 7 } & \multicolumn{1}{|c|}{$N$} & \multicolumn{1}{c|}{$\%$} & $N$ & \multicolumn{1}{c|}{$\%$} & \multicolumn{1}{c|}{$N$} & \multicolumn{1}{c|}{$\%$} \\
\hline Eódź & 234 & 89.7 & 65 & 85.5 & 299 & 88.7 \\
\hline Other & 24 & 9.2 & 8 & 10.5 & 32 & 9.5 \\
\hline Do not live in Poland & 3 & 1.1 & 3 & 3.9 & 6 & 1.8 \\
\hline Total & 261 & 100.0 & 76 & 100.0 & 337 & 100.0 \\
\hline
\end{tabular}


TR graduates more often live in cities of over half a million inhabitants: about $68.5 \%$ of TR compared to $44.6 \%$ of graduates in other fields (Table 8 ).

Table 8. FGS UŁ graduate size of home city by field of study

\begin{tabular}{|l|r|r|r|r|r|r|}
\hline \multirow{2}{*}{ Size of city } & \multicolumn{2}{|c|}{ Other } & \multicolumn{1}{c|}{$\begin{array}{c}\text { Tourism \& } \\
\text { Recreation }\end{array}$} & \multicolumn{2}{c|}{ Total } \\
\cline { 2 - 7 } & \multicolumn{1}{|c|}{$N$} & \multicolumn{1}{c|}{$\%$} & \multicolumn{1}{c|}{$N$} & \multicolumn{1}{c|}{ \% } & \multicolumn{1}{c|}{$\%$} \\
\hline Countryside & 68 & 26.4 & 13 & 17.8 & 81 & 24.5 \\
\hline City with population: & & & & & & \\
- up to 10000 & 12 & 4.7 & 1 & 1.4 & 13 & 3.9 \\
- from 10 000 to & 53 & 20.5 & 9 & 12.3 & 62 & 18.7 \\
$\quad$ 100 000 & & & & & & \\
- from 100 000 to & 10 & 3.9 & - & - & 10 & 3.0 \\
500 000 & 115 & 44.6 & 50 & 68.5 & 165 & 49.8 \\
\hline over 500 000 & 258 & 100.0 & 73 & 100.0 & 331 & 100.0 \\
\hline Total & & \multicolumn{5}{|r}{} \\
\hline
\end{tabular}

Women made up almost three quarters of those surveyed. For TR graduates this proportion was even higher - over $83 \%$ (Table 9).

Table 9. FGS UŁ graduate gender by field of study

\begin{tabular}{|l|r|r|c|r|r|r|}
\hline \multirow{2}{*}{ Gender } & \multicolumn{2}{|c|}{ Other } & \multicolumn{2}{c|}{$\begin{array}{l}\text { Tourism \& } \\
\text { Recreation }\end{array}$} & \multicolumn{2}{c|}{ Total } \\
\cline { 2 - 7 } & $N$ & $\%$ & $N$ & $\%$ & $N$ & $\%$ \\
\hline Female & 186 & 71.0 & 65 & 83.3 & 251 & 73.8 \\
\hline Male & 76 & 29.0 & 13 & 16.7 & 89 & 26.2 \\
\hline Total & 262 & 100.0 & 78 & 100.0 & 340 & 100.0 \\
\hline
\end{tabular}

\section{ADDITIONAL ACTIVITIES UNDERTAKEN DURING THE DEGREE COURSE}

It seems to be a quite common belief that additional activities help students to prepare better to enter the labour market. Such advice can easily be found published on popular Polish job offer portals: “A Master's degree doesn't make much impression on employers any more. However other activity does, especially before the first job - that's what can lift your listing. Work experience and internships are an opportunity to go beyond theoretical knowledge, see how a business works and how to apply academic knowledge on projects and in daily work" (kariera. pracuj.pl). This is why such additional activities are investigated. Fig. 1 shows the scale of uptake of six activities included in the UŁ survey.

It is difficult to talk about the differences in scale of activities presented in such a division: in each case, approximately $42-46 \%$ declared taking up at least one. TR students differ from others in types of activity and precise activities are shown in Table 10.

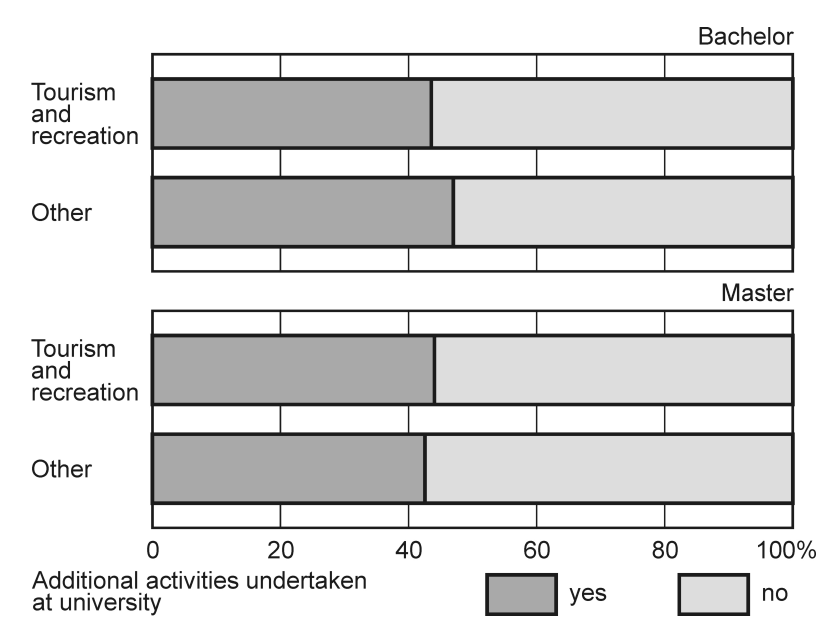

Fig. 1. FGS UŁ graduates undertaking additional activities at university by type and field of study Source for figs 1-8: own calculations based on 'Monitoring careers of UŁ graduates'

Table 10. FGS UŁ graduate type of additional activity at university by field of study ${ }^{a}$

\begin{tabular}{|l|c|c|c|c|c|c|}
\hline \multirow{2}{*}{$\begin{array}{c}\text { Additional activity } \\
\text { at university }\end{array}$} & \multicolumn{2}{|c|}{ Other } & \multicolumn{2}{c|}{$\begin{array}{c}\text { Tourism \& } \\
\text { Recreation }\end{array}$} & \multicolumn{2}{c|}{ Total } \\
\cline { 2 - 7 } & $N$ & $\%$ & $N$ & $\%$ & $N$ & $\%$ \\
\hline $\begin{array}{l}\text { Non-compulsory } \\
\text { internships }\end{array}$ & 40 & 34.8 & 7 & 20.6 & 47 & 31.5 \\
\hline Work experience & 13 & 11.3 & 6 & 17.6 & 19 & 12.8 \\
\hline Volunteering & 43 & 37.4 & 12 & 35.3 & 55 & 36.9 \\
\hline $\begin{array}{l}\text { Student } \\
\text { organizations }\end{array}$ & 15 & 13.0 & 5 & 14.7 & 20 & 13.4 \\
\hline $\begin{array}{l}\text { Student research } \\
\text { groups }\end{array}$ & 37 & 32.2 & 7 & 20.6 & 44 & 29.5 \\
\hline $\begin{array}{l}\text { Student exchange } \\
\text { programs }\end{array}$ & 17 & 14.8 & 14 & 41.2 & 31 & 20.8 \\
\hline Total & 115 & 100.0 & 34 & 100.0 & 149 & 100.0 \\
\hline
\end{tabular}

${ }^{a}$ - Responses to multiple choice questions.

TR students took part more often on student exchange programs, and less frequently in non-compulsory work experience and student research groups. Due to the small number of cases ( $n=34$ for TR) this difference must be treated with caution.

A slightly different issue is paid employment while studying. Early experience of work seems to be treated as an important factor of success in the labour market. In the article cited above the authors state: "The sooner we begin to gain professional experience, the faster we became independent and confident in the labour market" (Kariera.pracuj.pl). On the other hand, it can be argued that not all types of work undertaken by a student will be valuable for their future career. The results presented in "Model employment status of graduates" indicate that the form of student employment has a statistically significant impact on the status of graduate employment. The scale of paid employment during a degree is shown in Fig. 2. 


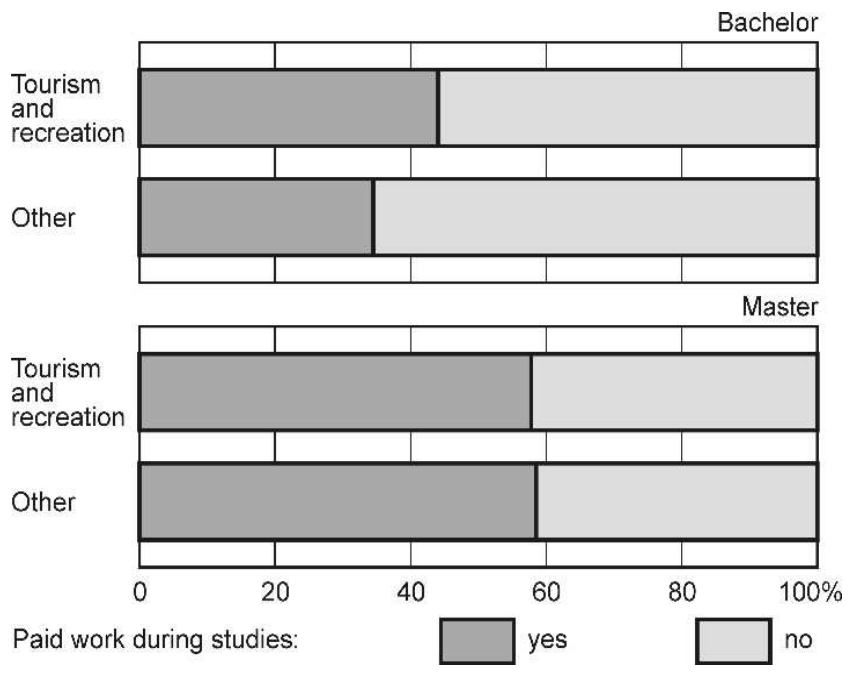

Fig. 2. FGS UŁ graduate paid work during a degree course by type and field of study

TR graduates took paid employment during their degrees more frequently than other fields of study. There is a clear difference in the scale of employment between TR and 'Other' students.

Table 11. FGS UŁ graduate forms of employment during a degree course by field of study ${ }^{a}$

\begin{tabular}{|l|r|r|r|r|r|r|}
\hline \multirow{2}{*}{$\begin{array}{c}\text { Form of employment } \\
\text { contract }\end{array}$} & \multicolumn{2}{|c|}{ Other } & \multicolumn{2}{|c|}{$\begin{array}{c}\text { Tourism \& } \\
\text { Recreation }\end{array}$} & \multicolumn{2}{|c|}{ Total } \\
\cline { 2 - 7 } & \multicolumn{1}{|c|}{$\%$} & \multicolumn{1}{c|}{$N$} & \multicolumn{1}{c|}{$\%$} & \multicolumn{1}{|c|}{$N$} & \multicolumn{1}{c|}{$\%$} \\
\hline Own business & 6 & 3.4 & 1 & 1.8 & 7 & 3.0 \\
\hline Full-time employment & 25 & 14.0 & 10 & 18.2 & 35 & 15.0 \\
\hline Part-time employment & 32 & 18.0 & 1 & 1.8 & 33 & 14.2 \\
\hline $\begin{array}{l}\text { Contract (including } \\
\text { paid work experience) }\end{array}$ & 125 & 70.2 & 40 & 72.7 & 165 & 70.8 \\
\hline $\begin{array}{l}\text { Contract for specific } \\
\text { work }\end{array}$ & 22 & 12.4 & 4 & 7.3 & 26 & 11.2 \\
\hline $\begin{array}{l}\text { Work without } \\
\text { a contract }\end{array}$ & 34 & 19.1 & 10 & 18.2 & 44 & 18.9 \\
\hline Total & 178 & 100.0 & 55 & 100.0 & 233 & 100.0 \\
\hline
\end{tabular}

$a$ - Responses to multiple-choice questions.

As a whole, above $70 \%$ worked on a contract (including paid work experience), and least often ran their own business. TR graduates less frequently indicated working part-time (Table 11).

\section{EMPLOYMENT A YEAR AFTER GRADUATION}

About two thirds of surveyed graduates answered affirmatively that they have a job at the moment. In terms of fields of study the percentage of employed graduates was highest for TR (Fig. 3).

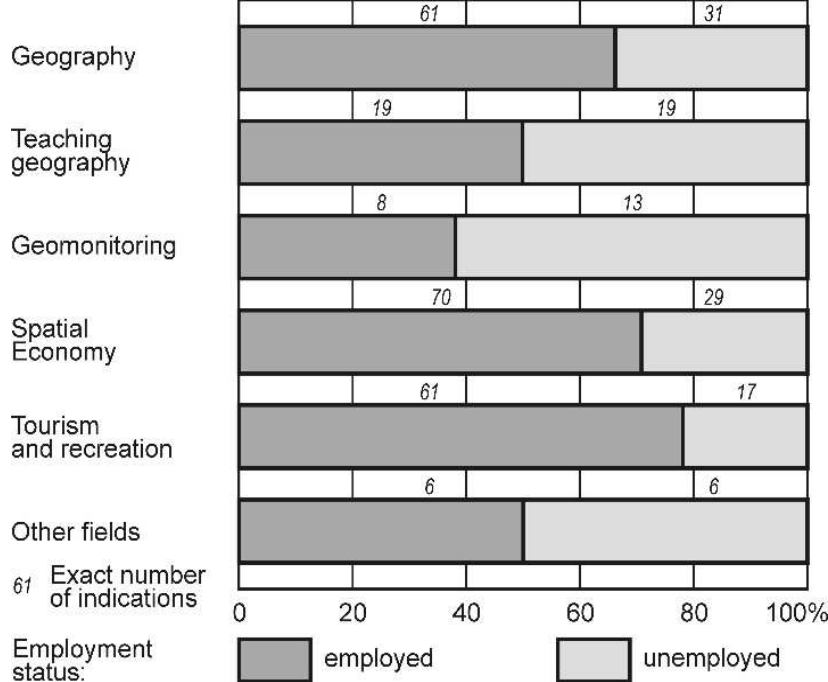

Fig. 3. FGS UŁ graduate employment status for all fields of study

The difference in the level of employment differs strongly by type of degree. Just about $40 \%$ of graduates with a Bachelor degree were employed, which is half as much as those with a Master's degree (80.5\%). Among TR graduates levels of employment are higher than for graduates from other fields. This difference is visible also by the type of degree, as shown in Fig. 4.

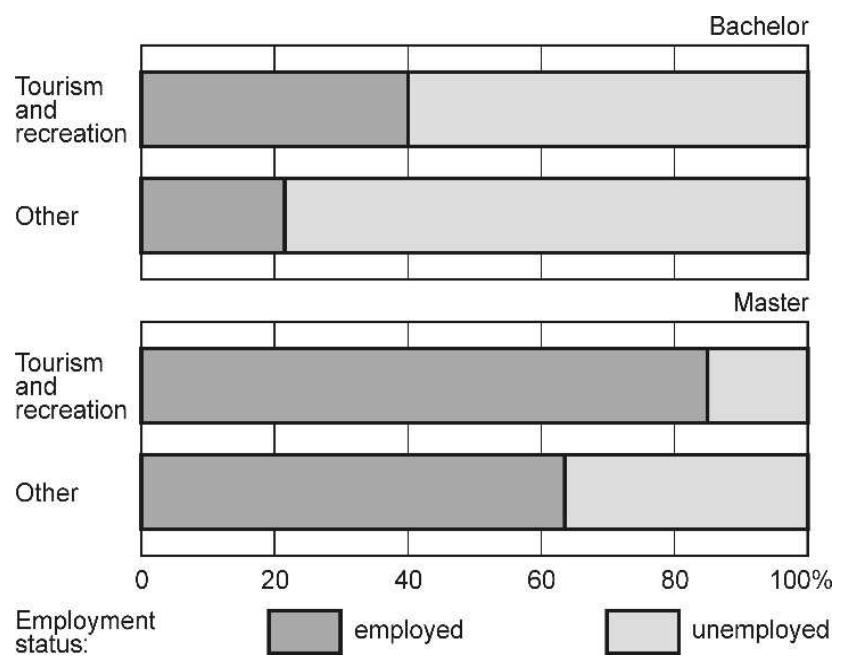

Fig. 4. FGS UŁ graduate employment status by type and field of study

Knowing the scale of graduate employment, the characteristics of those employed an be investigated. Respondents were asked the number of places where they worked simultaneously. The term portfolio workers is understood as "those that work for more than one employer" (LIPIŃSKA-GROBELNY 2014, p. 9). The proportion of such workers is much higher for TR graduates as shown in Fig. 5. 


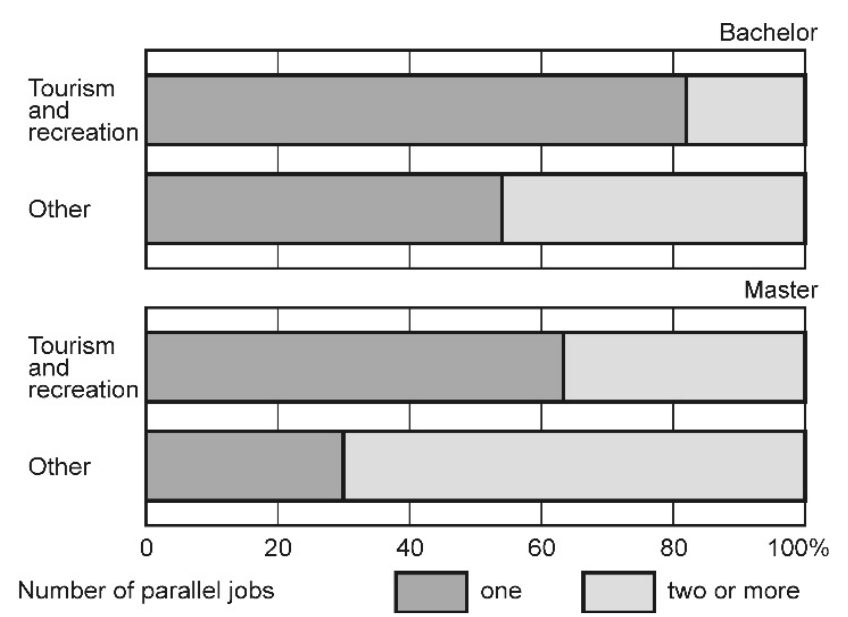

Fig. 5. FGS UŁ graduate parallel jobs by type and field of study

Due to the purpose and scope of this article, and a large number of categories in the following sections comparisons between fields of study are omitted, only TR graduates $(n=61)$ are reported and only those in employment (see Fig. 3). The division by type of study is present because of the differences between these groups.

TR Bachelor graduates most often indicated that their gross monthly earnings at university are less than 1,000 zł. For Master's was 1,501-2,000 zł (Fig. 6). Note in Figs 6, 7 and 8 the numerical scale shows the number of responses. Please note also that the size of the Bachelor group was less than the Masters.

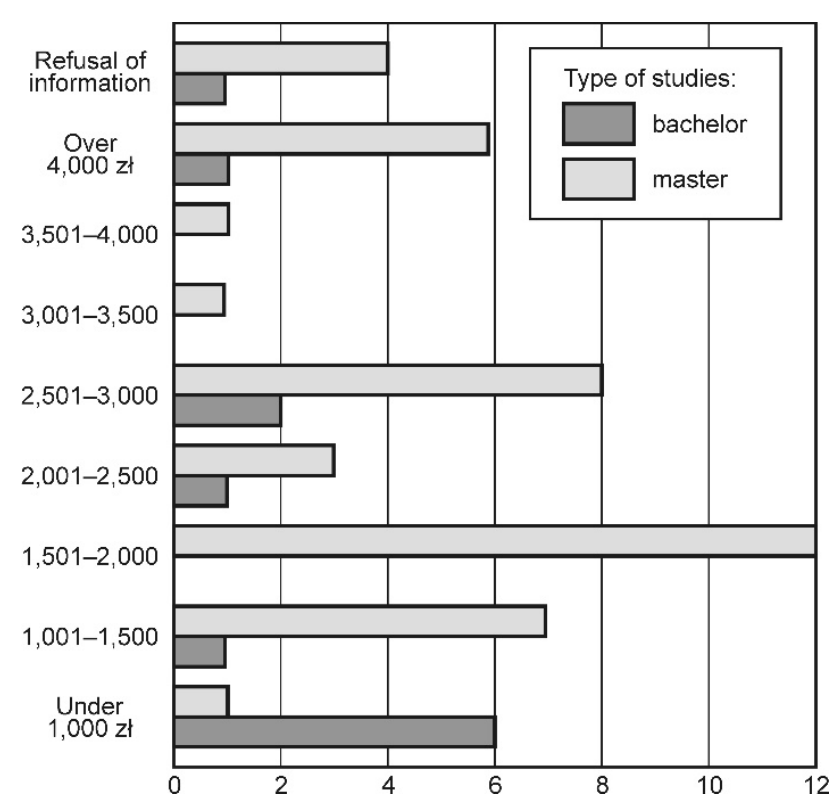

Fig. 6. TR UŁ graduate monthly gross earnings by type of study

More than half of Bachelors and about two thirds of Masters found their work compatible with their education. In the first group answers were 'rather yes', the second 'definitely yes' (Fig. 7).

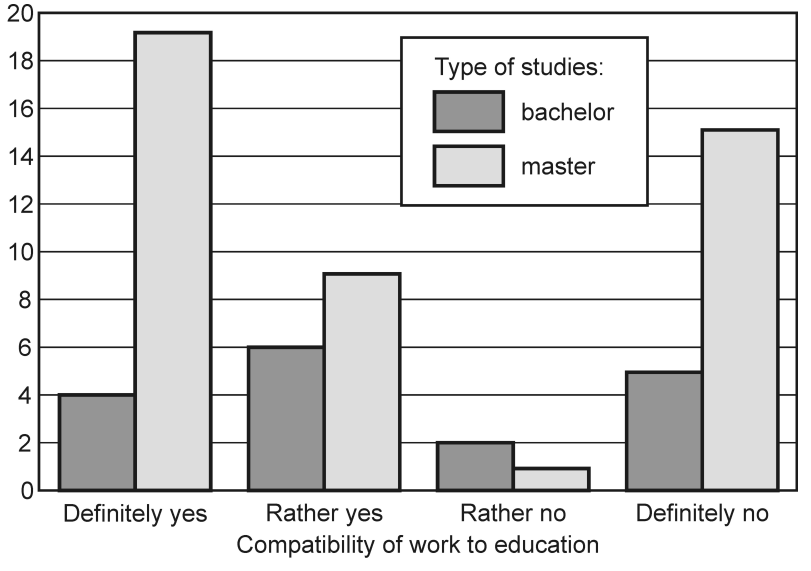

Fig. 7. TR UŁ graduate compatibility of work to education by type of study

It is worth considering how the respondents understand the question of compatibility of work with education, because a seemingly similar request for an assessment of the use of the knowledge and skills acquired at university for work gave different results. Answers 'definitely' and 'rather yes' were chosen by less than a third and a half of Bachelors' and Masters' students respectively (Fig. 8).

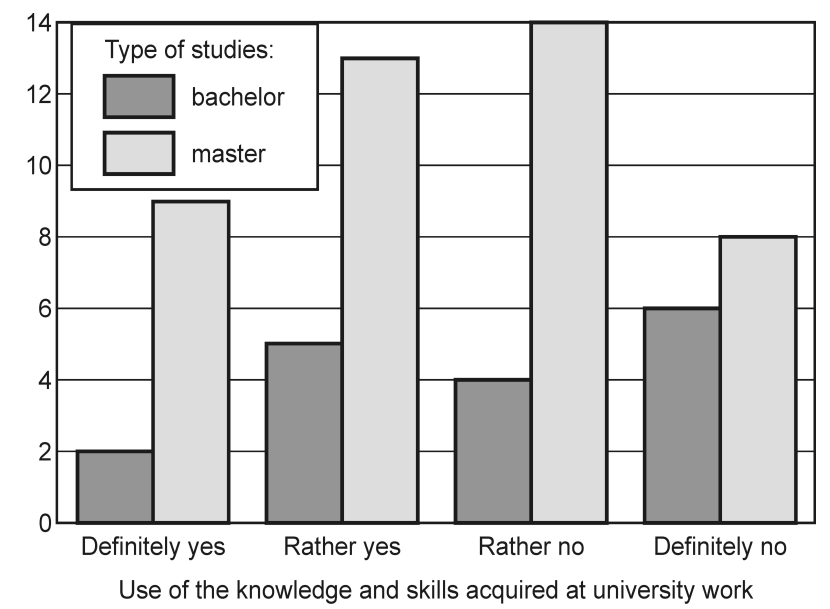

Fig. 8. TR UŁ graduate use of knowledge and skills acquired at university for work by type of study

Comparing items indicates that only respondents choosing 'definitely not' in the question of the compatibility gave only negative answers for the question about the use of knowledge/ skills acquired at university. Thus, some TR graduates consider their work to be compatible with education, and at the same time believe that they mostly do not use knowledge and skills acquired at university for this work. There are individuals declaring 'opposites': work inconsistent with education and use acquired knowledge/skills for work. 


\section{MODEL OF GRADUATE EMPLOYMENT STATUS}

The search for answers to the main question: 'What determines the status of graduate employment?' led to the use of a logistic regression model. The dependent (target) variable was the current employment status of graduates: 0 - unemployed, 1 - employed. Logistic regression is a typical modelling technique for dichotomous dependent variables 'failure/ success' (FIELD 2013, DANIELUK 2010, BEDYŃSKA \& BRZEZICKA 2007).

In the phase of data exploration there was a search for potential predictors (independent variables), while looking for variables related to the dependent variable (LAROSE 2006, pp. 45-51). Chi ${ }^{2}$ test of independence was performed for target variables versus each of twenty-three independent variables - addressed to all respondents (excluding those addressed only to employed graduates). For six independent variables the test results were statistically significant or of borderline significance. Those variables were included as employment status predictors in the first version of the model. The 'enter method' was used. Then a final model consisting of five independent variables for which the first version achieved a statistically significant result. The 'enter method' was used here, too. Modelling was made with $n=331$ FGS graduate due to nine item nonresponse present in the model.

Table 12 shows the parameters of the independent variables of the final version of the model.

Table 12. Parameters of logistic regression model predictors

\begin{tabular}{|l|l|c|c|c|c|}
\hline \multicolumn{2}{|c|}{ Predictor } & $B$ & $d f$ & $p$ & $\operatorname{Exp}(B)$ \\
\hline \multirow{4}{*}{$\begin{array}{l}\text { Step } \\
\text { 1. }\end{array}$} & Field of study & 0.861 & 1 & 0.020 & 2.365 \\
\cline { 2 - 6 } & Type of study & 1.895 & 1 & 0.000 & 6.655 \\
\cline { 2 - 6 } & Mode of study & -1.867 & 1 & 0.021 & 0.155 \\
\cline { 2 - 6 } & $\begin{array}{l}\text { Form of employ- } \\
\text { ment during } \\
\text { studies }\end{array}$ & 0.951 & 1 & 0.001 & 2.588 \\
\cline { 2 - 6 } & $\begin{array}{l}\text { Size of place of } \\
\text { residence (1) }\end{array}$ & 0.423 & 1 & 0.573 & 1.526 \\
\cline { 2 - 6 } & $\begin{array}{l}\text { Size of place of } \\
\text { residence (2) }\end{array}$ & -0.136 & 1 & 0.734 & 0.873 \\
\cline { 2 - 6 } & $\begin{array}{l}\text { Size of place of } \\
\text { residence (3) }\end{array}$ & 2.181 & 1 & 0.014 & 8.853 \\
\cline { 2 - 6 } & $\begin{array}{l}\text { Size of place of } \\
\text { residence (4) }\end{array}$ & 0.536 & 1 & 0.117 & 1.710 \\
\cline { 2 - 6 } & $\begin{array}{l}\text { Size of place of } \\
\text { residence }\end{array}$ & $\begin{array}{c}\text { not } \\
\text { applicable }\end{array}$ & 4 & 0.047 & $\begin{array}{c}\text { not } \\
\text { applicable }\end{array}$ \\
\cline { 2 - 6 } & Constant & 0.785 & 1 & 0.375 & 2.193 \\
\hline
\end{tabular}

The identified predictors impacts on the target variable are described by $\operatorname{Exp}(\mathrm{B})$, defined as the 'odds ratio' - an indicator of the odds changing as a result of a unit change in the independent variable. Thus, for the four dichotomous predictors used:
1. Field of study: 0 - all other fields grouped, 1 - TR; the odds of a graduate who is a TR graduate being employed are 2.4 times higher than those of other graduates

2. Type of study: 0 - bachelor, 1 - master; the odds of a master's graduate being employed are 6.7 times higher than those of a bachelor.

3. Mode of study: 0 - part-time 1 - full-time; the odds of a full-time graduate being employed are $6.5^{1}$ times lower than part-time.

4. Selected forms of employment - work during university: 0 - running own business, or contract, or working without a contract, or not working, 1 - full-time employment, or part-time employment, or contract (including paid practices).

Such selection was based on the results from the data - only for forms of employment grouped under the code ' 1 ' did $c h i^{2}$ tests of independence give statistically significant results. Positive values of the association strength phi indicated that there is a positive correlation (NAWOJCZYK 2002, pp. 223-4) between working within these employment types, and 'being employed' a year after graduation; the odds of an graduate who is in the code ' 1 ' being employed are 2.6 times higher than those in code ' 0 ' (see Table 7).

The size of place of residence was recoded into dummy variables. Such variables are dichotomous indicating various categories of a factor: 0 - no, 1 - yes, and are one less than the number of categories, because one category is the default. Its value is 'yes' when all the other dummy variables are 'no' (LAROSE 2006, pp. 133). In this case it is the 'countryside' category used in reference to the others, thus:

1) the odds of a graduate living in a city up to 10,000 being employed is 2.6 times higher,

2) the odds of a graduate living in a city from 10 to 100,000 being employed is 1.1 times lower,

3) the odds of a graduate living in a city from 100 to 500,000 residents being employed is 8.9 times higher ${ }^{2}$,

4) the odds of a graduate living in a city over 500,000 residents being employed is 1.7 times higher.

The model is statistically significant and the average fitted to the data:

- $\operatorname{chi}^{2}(8)=100.82, p<0.001$.

- pseudo $R^{2}=0.26$ (Cox and Snell), 0.36 (Nagelkerke).

Accuracy of the model was $75.8 \%$, with a specificity of $54.8 \%$ (correct classification of 'unemployed') and sensitivity of $87 \%$ (correct classification of 'employed'). Thus, this model performs less accurately in predicting unemployment (Table 13).

A larger classification error of 'unemployed' status was found in the work by Piróg. The specificity of this model was of $75.6 \%$, with a sensitivity of $81.3 \%$. Total 
Table 13. Confusion matrix of logistic regression model

\begin{tabular}{|c|l|l|c|c|c|}
\hline \multicolumn{2}{|c|}{ Observed } & \multicolumn{2}{c|}{ Predicted } \\
\cline { 3 - 5 } \multicolumn{2}{|c|}{} & \multicolumn{2}{c|}{ employment status } & \multirow{2}{*}{ percentage of correct classification } \\
\cline { 3 - 5 } \multirow{3}{*}{ Step 1. } & \multirow{2}{*}{\begin{tabular}{l} 
Employment status \\
\cline { 3 - 5 }
\end{tabular}} & unemployed & 63 & 52 & 54.8 \\
\cline { 2 - 5 } & Percentage of Total & employed & not applicable & not applicable & 87.0 \\
\hline
\end{tabular}

accuracy of PIRÓG's (2015, p. 166) model predictions for the test group was $78.5 \%$. The classification is therefore more precise than in the model proposed in this article, especially when discussing about unemployment prediction. However, note that the model Piróg used was much more complex - 28 predictors for 375 observations (PIRÓG 2015, pp. 161-2), and in this article, five predictors for 331. Considering that, increasing the number of observations or reducing the number of predictors in the more complex model might be recommended (FIELD 2009, pp. 222-3). However, because of the practical application potential of the results of such analyses in supporting the students or graduates, correct classification of the unemployed - or de facto the risk factors of unemployment - is exceptionally important.

Special attention was paid to variables that due to the results of the analysis were not included in the model proposed here, but may seem to have a positive impact on graduate careers.

The first is activity in student research groups during university. For this variable the independence test used in the exploration phase was statistically significant $\operatorname{ch~}^{2}(1.340)=4.37, p<0.05$. The negative value of $p h i=-0.13$ stands for a week negative correlation (NAWOJCZYK 2002, pp. 223-224) between such activities - involved in a student research group - and employment status a year after graduation (Table 14). Within respondents who declared such an activity the proportion of employed graduates was lower than for those who did not got involved.

Table 14. FGS UŁ graduate employment status by activity in student research groups

\begin{tabular}{|l|c|c|r|c|}
\hline \multirow{2}{*}{ Employment status } & \multicolumn{4}{|c|}{ Activity in a student research group } \\
\cline { 2 - 5 } & \multicolumn{2}{|c|}{ yes } & \multicolumn{2}{c|}{ No } \\
\cline { 2 - 5 } & $N$ & $\%$ & $N$ & $\%$ \\
\hline Employed & 23 & 52.3 & 202 & 68.2 \\
\hline Unemployed & 21 & 47.7 & 94 & 31.8 \\
\hline Total & 44 & 100.0 & 296 & 100.0 \\
\hline
\end{tabular}

None of the additional activities surveyed (noncompulsory internships, work experience, volunteering, participation in student organizations, participation in student exchange programs) nor any of the activities grouped as 'did/did not undertake at least one activity' showed a correlation with the target variable. Chi $i^{2}$ tests gave non-significant results for all of those items.

\section{CONCLUSIONS}

The model proposed in this paper managed to correctly predict graduate employment status for about $3 / 4$ of cases for 'being employed'. Four of five predictors used are structural or institutional characteristics: the size of the place of residence, mode, level and field of completed studies. The only behavioural characteristic included was undertaking paid work during university - selected forms of employment: running own business, or on contract, or working without a contract or not working, as one category; full-time employment, or part-time employment, or contract (including paid work experience) as the other.

The surprising fact is that there was no significant relationship for any other additional activity with 'being employed' by the statistical tools used here. Radically simplified, the application reads as follows: a student who had a job will more likely have a job a year after graduation. In support of this, according to a survey conducted by the Career Office of the University of Łódź about $48 \%$ of all working FGS graduates declared that they continue the job undertaken during their degree. The relationship described above may indicate the labour market value of gaining such work experience. The importance of such experience was underlined by the authors of a qualitative study devoted to preparing students for work in LTR (Leisure, Recreation and Tourism). Both professionals and students were interviewed and all professionals stressed the importance of work experience in entering the labour market in the LTR (CHEN \& GURSOY 2008, p. 34).

The type and field of study are other interesting employment status predictors. As to the first, it is clear that bachelor degree graduates mostly do not fully enter the labour market - about $40 \%$ of the group worked a year after graduation, and nearly all the unemployed declared 'continuing education'. The 
second predictor - field of study - should be treated carefully. Although attractive, it would be an erroneous statement that 'it is better to study TR than any of the other FGS fields'. For the purposes of this article, fields of study were artificially aggregated into TR/Other, to emphasize the differences. Thus, it can only be stated that the odds of a graduate who is who is a TR graduate being employed are higher than those of an 'Other' graduate.

Undoubtedly, the model obtained may be affected by the problem of sample unrepresentativeness. If the sample is representative for a field of study with 100 graduates per year for example, there should be a 79 graduate random sample of this field ${ }^{3}$ (BABBIE 2003). The current process of collecting consents to participate in career monitoring and implementation of the survey itself makes this virtually impossible. Therefore seeking to increase the number of consents and survey responses is needed, and there is a need to inform and to promote career monitoring among students and staff of the University of Łódź.

To conclude, the legitimacy of this article's main question must be discussed. The target variable was graduate employment status, and 'employed' was treated as a success. Behind that target, there seems to be an assumption about the purpose of education at university. Therefore, the aim of a university education - that success - is achieved when a graduate has a job one year after graduation. Such an assumption is in a way modernist and neo-liberal: higher education gives a job, and the job is treated unambiguously as a value. The aim of education, and in fact the role of the university is considered to be pragmatic. The problem of 'engaged university' (Uniwersytet zaangażowany 2010) or 'temple of knowledge' (CZEŻOWSKI 1946) raised in humanist discussions is omitted here. Moving away from the assumed function to the real function of a university was considered a kind of a global trend 15 years ago (KOBYLAREK 2002, p. 90), perhaps an expression of this trend is also analysis included in this article.

In addition, is the year after graduation the right time for 'evaluation'? And if so, how to evaluate a situation in when a graduate still works where they worked as a student? Without a doubt, this field requires in-depth analysis. Authors taking up the graduate career issue underline both the need to study labour market trends (Kruk 2007, Suchorab 2015), individual psychosocial characteristics - the mostly broadly defined competences (ROGOZIŃSKA-PAWEECZYK \& MAJEWSKI 2011, WIECHETEK \& TALIK 2014), as well as socioeconomic macro-processes (ZIELIŃSKA 1997, SMARZEWSKA 2016). Similarly, in Piróg's model: 28 predictors showed both psychological and behavioural characteristics, as well as the plans and opinions of respondents (PIRÓG 2015, p. 161). It seems that similar studies should take into account all sorts of variables, as well as the use of qualitative research. Research focused on the diagnosis of the assumed function of a university should also be considered.

\section{ENDNOTES}

1 Because $\operatorname{Exp}(B)<1$, it is easier to interpret the odds ratio expressed as $1 / \operatorname{Exp}(B): 1 / 0,155=6,45$.

2 Only this particular category of size of city differed statistically significantly from the default category, however the size of city as a whole was a statistically significant predictor: note $p<$ 0.05 in a row where four degrees of freedom are reported (see Table 11).

${ }^{3}$ Assuming the $95 \%$ confidence level, at 0.5 and a maximum error of $5 \%$.

\section{BIBLIOGRAPHY}

BABBIE E., 2003, Badania społeczne w praktyce, Wyd. Naukowe PWN, Warszawa.

KREJTZ I., KREJTZ K., 2007, Wprowadzenie do analizy regresji jedno- i wielozmiennowej, [in:] S. Bedyńska, A. Brzezicka (eds.), Statystyczny drogowskaz. Praktyczny poradnik analizy danych w naukach społecznych na przykładach z psychologii, Wyd. SWPS 'Academica', Warszawa, pp. 364-384.

BEDYŃSKA S., BRZEZICKA A., 2007, Statystyczny drogowskaz, Wyd. SWPS 'Academica', Warszawa.

CHEN B.T., GuRsoy D., 2008, Preparing Students for Careers in the Leisure, Recreation and Tourism Field, Journal of Teaching in Travel \& Tourism, 7, 3, pp. 21-41.

BRZEZIŃSKI J., 2003, Metodologia badań psychologicznych, Wyd. Naukowe PWN, Warszawa.

CZEŻOWSKI T., 1946, O uniwersytecie $i$ studiach uniwersyteckich, Księgarnia Naukowa T. Szczęsny i S-ka, Toruń, 67 pp.

DANIELUK B., 2010, Zastosowanie regresji logistycznej w badaniach eksperymentalnych, Psychologia Społeczna, 5, 2-3 (14), pp. 199-216

FIELD A., 2009, Discovering Statistics Using SPSS, SAGE Publications Ltd., London.

KOBYLAREK A., 2002, Uniwersytet - zarys idei podstawowej, Nauka i Szkolnictwo Wyższe, 1, pp. 90-100.

KRUK M. (eds.), 2007, Studia $i$ co dalej... Sytuacja studentów na rynku pracy, Uniwersytet w Białymstoku, Białystok, 214 pp.

LAROSE D.T., 2006, Odkrywanie wiedzy z danych. Wprowadzenie do eksploracji danych, Wyd. Naukowe PWN, Warszawa.

LIPIŃSKA-GROBELNY A., 2014, Zjawisko wielopracy. Psychologiczne uwarunkowania $i$ konsekwencje, Wyd. Uniwersytetu Łódzkiego, Łódź, 247 pp.

LISZEWSKI S., 2010, Tourism studies: situated within multiple disciplines or a single independent discipline? (Discursive article)/ Nauka czy nauki o turystyce (artykuł dyskusyjny), Tourism/Turyzm, 20, 2, pp. 37-44.

NAWOJCZYK M., 2002, Przewodnik po statystyce dla socjologów, SPSS Polska, Kraków.

PAŁASZ L., 2004, Kształcenie oraz losy absolwentów, Wyd. Akademii Rolniczej w Szczecinie, Szczecin.

PIRÓG D., 2015, Przechodzenie absolwentów studiów geograficznych na rynek pracy. Proces, czynniki, predykcja, Wyd. Naukowe UP, Kraków, 266 pp. 
ROGOZIŃSKA-PAWEECZYK A., MAJEWSKI D. (eds.), 2011, Absolwent na rynku pracy, Wyd. Uniwersytetu Łódzkiego, Łódź, 233 pp.

SMARZEWSKA A., 2016, Bezpieczeństwo edukacyjne absolwentów szkót wyższych, Wyd. Państwowa Szkoła Wyższa JPII, Biała Podlaska, $160 \mathrm{pp}$.

SUCHORAB A., 2015, Wybory edukacyjno-zawodowe w biografiach studentów na tle wyzwań wspótczesnego rynku pracy, Wyd. Naukowe Wyższej Szkoły Informatyki i Zarządzania im. Profesora T. Kotarbińskiego, Olsztyn, 452 pp.

SZCZEPAŃSKI J., 1963, Socjologiczne zagadnienia wyższego wyksztatcenia, Państwowe Wyd. Naukowe, Warszawa.

TALIK W., WIECHETEK M. (eds.), 2014, Kwestionariusz istotnych kompetencji w poszukiwaniu zatrudnienia (KIK-PZ), OIC Poland, Lublin, 129 pp.
ZARZECKI M., Borne-JANuŁA H., JAROSZEK K., PUCHALSKA K., PIOTROWSKA P., NOISZEWSKI Ł., 2010, Losy absolwentów szkót i uczelni ksztatcących kadry dla turystyki, Ministerstwo Sportu i Turystyki, Warszawa, 323 pp., https://www.msit.gov.pl/ download/1/4285/w2010f2ef.pdf, 05.07.2017.

Uniwersytet zaangażowany. Przewodnik krytyki politycznej, 2010, Zespół Krytyki Politycznej, Wyd. Krytyki Politycznej, Warszawa, 352 pp.

ZIELIŃSKA M., 1997, Kariery zawodowe absolwentów wyższej uczelni, Lubuskie Towarzystwo Naukowe, Zielona Góra, 206 pp., http:/ / biurokarier.uni.Łódź.pl/projekty-biura-karier/moni torowanie-karier-absolwentow/, 23.03.2017.

http://ela.nauka.gov.pl/includes/pdf/opis_raportow.pdf; 4.07 . 2017.

https:// kariera.pracuj.pl/rozmowa_kwalifikacyjna/5-powodowdla-ktorych-warto-isc-na-staz/; 21.03.2017.

\section{Acknowledgement}

Author of this paper would like to thank the President of University of Eódź Careers and Cooperation with Employers Centre, Dariusz Koperczak PhD for allowing the use of survey data collected for 'Monitoring careers of UE graduates'. 